\title{
Organized Retail Strategy - A Study at Loyal World Supermarket
}

\author{
Aluregowda \\ Assistant Professor Post Graduate Department of Management Studies PES College of Engineering, Mandya.
}

\begin{abstract}
Indian retail has traditionally been an unorganized sector, where retailers lacked the means as well as the will to develop or expand. Retail could also never enjoy the support of the Indian consumer, who is famous for being miserly and who treats shopping as a form of leisure, enjoying the thrill of discovering bargains and discount deals in his own time. The western attitude of splurging, indulging and shop-till-youdrop has slowly entered the country and led to organized retailing. The purpose $f$ the study is to determine the influence of selected strategies on the growth of the business. The convenience sampling method was used and the data was collected from the loyal world supermarket managers. The results revealed that all the selected strategies are positively related to growth of the business.
\end{abstract}

Keywords- Organized retailing, Strategies, Loyal world supermarket

\section{Introduction}

In India, over 94 percent of the retail sector consists of traditional mom-and-pop stores and streetvendors. While in most countries it is the organized retailers who dominate the sector, in India, the unorganized retailers command about 94 percent of the market share. Most traditional retail shops have a shop forming the frontage of their residence and the business is conducted by family members who reside in the house behind. Traditional retailers usually stocked only some high-margin brands. Small shop-owners maintained good customer relations and sold products on credit to people in the neighbourhood. More than 99 percent of the retailers functioned from less than 500 sq. $\mathrm{ft}$. of shopping space. With no large players, infrastructure being far from adequate, Indian retail never attracted large business houses that predominantly focused on niche product segments and luxury goods. This was till these businesses realized that retail in India is a USD 353 billion industry growing at a Compound Annual Growth Rate (CAGR) of more than 11 percent and contributing more than 25 percent to the country's GDP. The retail sector also employs about 8 percent of the country's population.

\section{Review Of Literature}

Every thesis necessarily undertakes a brief review of previous studies on the problem and the significant contributions made by several Researchers on the topic under study. Such review is meant to provide a summary of the current state of knowledge in the area being investigated, the research gaps that possibly obtain and how the present study proposes to bridge the said gap. The underlying purpose is to locate the present research in the existing body of research on the subject and point out what it contributes to the subject.

Accordingly, a review of literature on the topic under study is made in the following paragraphs.

G Ramesh, Simmi Prasad and Sonia Goyal in "A Pilot Study of Organized Retail Formats and their Location Strategy in Mumbai," point out that location decisions are complex in nature. The cost of selecting a location is very high, and there is little flexibility once the location is chosen. A good location may lead to the success of an outlet even if other strategies are weak. The choice of location depends on population size and trait, market competition, transportation access, parking availability, nature of nearby stores, property cost, and length of the agreement, legal restrictions and other factors. They cite to drive home the point that the proximity of customers to a retail outlet relative to other outlets makes a significant difference to the revenue earned by the outlet. The study uses various international theories to emphasise these points. This study uses five different parameters (location, proximity to competitor, property rate, population characteristic, and parking) to evaluate and compare the specific brands of three main retail outlets, namely: Big Bazaar, Spinach,Shoppers Stop

The study concludes that there exists a relationship between the format of the retail store and its location. Before deciding on a location for a new store of a particular format, the retailers should take into account the catchment area, competitors, the income profile of the people living in the trade area, their lifestyle and demographic factors.

This is a simple study with straight forward objectives. It studies the general view that retail format is dependent upon the location; this is generally true in most cases. Most organized retailers undertake exhaustive 
surveys about the demography, earning levels, presence of competitors, and availability of products before deciding to start business in any location. Other factors such as competition, staff retention, or customer satisfaction are not covered by this study. The accuracy of the third part of the study where there is a comparison and analysis of profitability is debatable though.

Business and Finance Information, a website based in USA, in its research article "Retail Industry in India: Challenges, Opportunities, and Strategies" declares that the retailing industry in India is in its peak stage having opened in 1995.The website summarises the organized retail strategies in four stages: introduction, growth, maturity, decline For the first phase the suggested strategy is rapid penetration with low price and high promotion so that consumers can start the habit of visiting the organized retail stores and modifying their lifestyle, to one of more spending, rather than saving. For the second phase of growth, the strategy to be used is adopting quality and high-style products with new models and shift of advertising from product awareness to product preference. In the maturity phase, retailers can enter new geographic areas, such as tier II and tier III cities or have niche formats to cater to certain groups of customers. In the decline phase, with closing of the window of opportunity, it would be a good strategy to identify weak segments and maintain investment selectively.

Organized retail accounts for only about 3 percent of the total retail sector and is expected to grow at more than 30 percent for the next few years. The status of the retail industry will depend mostly on external factors like government regulations and policies and real estate prices, employee retention; besides the activities of retailers and demands of the customers will also show impact on retail industry.

This paper gives a reasonable synopsis of the factors involved, staging them appropriately. While all the complex factors are not analysed in depth, most of them are covered. This article also does not consider the inputs from the valuable experience that the current organised retail players have gained in the past 5-10 years of operation.

D Gayatri and T Phani Madhav in their study titled "Organised Retailing in India - Opportunities and Challenges" discuss the evolution of organised retailers in India. The objective of their study is to find out whether hypermarkets can emerge as a pan-Indian retailing format despite the impediments. Retailing, as long as it was limited to the unorganised corner stores, provided customers with limited choice and services. But with the entry of Big Bazaar, Tata, Reliance, and Shoppers Stop into the organised retailing sector, there has been a sea change in the landscape, according to the Rsearchers. While organised retail will eventually have a pan-Indian presence, it will not fully displace the traditional retailers who can provide services like monthly credit and instant home delivery. The study describes the great Indian retail fight, that is, small retailers versus organised retail, but provides no new insight.

Aditya P. Tripathi of the Delhi School of Professional Studies and Research, in his research paper "Emerging Trends in Modern Retail Formats \& Customer Shopping Behavior in Indian Scenario", differs with other scholars in that he argues that "place is no longer important" and rural and semi-urban areas have as much potential as the city areas provided there is a right value proposition. He cites the example of Wal-Mart which started in the rural market and is now an unquestionable global giant.

\section{Objective Of The Study}

1. To study the various selected strategies used by the big bazaar retailers.

2. To determine the influence of selected strategies on the growth of the business.

\section{HYPOTHESIS}

1. There is no significant positive relationship between the selected strategies and the growth of the business.

\section{SCOPE}

The study is confined to Mysore district only. The data was gathered through interview therefore it might contain respondent bias. The study can be extended for managers across different supermarkets in further geographical area.

\section{Methodology}

The data for the research has been collected through personal interview with the various managers of the big bazaar by using the structured questionnaire. The secondary data has been collected from books and journals. 


\section{Data Analysis And Interpretation}

Join hands with other organized retailers to form an association

\begin{tabular}{|ll|r|r|r|r|}
\hline & $\begin{array}{c}\text { Frequen } \\
\text { cy }\end{array}$ & Percent & $\begin{array}{c}\text { Valid } \\
\text { Percent }\end{array}$ & $\begin{array}{c}\text { Cumulative } \\
\text { Percent }\end{array}$ \\
\hline Valid & YES & 8 & 80.0 & 80.0 & 80.0 \\
& NO & 2 & 20.0 & 20.0 & 100.0 \\
& Total & 10 & 100.0 & 100.0 & \\
\hline
\end{tabular}

The descriptive analysis revealed that Join hands with other organized retailers to form an association has been used by eight managers of big bazaar indifferent geographical areas in order to obtain sustainable high growth in the business and two of the managers have not used this strategy.

Use professionally trained security staff, CCTV, and EAS

(Electronic Article Surveillance) to prevent pilferage

\begin{tabular}{|rc|r|r|r|r|}
\hline & $\begin{array}{c}\text { Frequenc } \\
\mathrm{y}\end{array}$ & Percent & $\begin{array}{c}\text { Valid } \\
\text { Percent }\end{array}$ & $\begin{array}{c}\text { Cumulative } \\
\text { Percent }\end{array}$ \\
\hline Valid & YES & 7 & 70.0 & 70.0 & 70.0 \\
& NO & 3 & 30.0 & 30.0 & 100.0 \\
& Total & 10 & 100.0 & 100.0 & \\
\hline
\end{tabular}

The above results reveals that seven of the managers prefer Use professionally trained security staff, CCTV, and EAS (Electronic Article Surveillance) to prevent pilferage as a strategy to increase the profit level and remaining three managers do not implement this strategy.

\begin{tabular}{|c|c|c|c|c|c|}
\hline \multicolumn{6}{|c|}{ Attempt cost-cutting } \\
\hline & & $\begin{array}{c}\text { Frequenc } \\
\mathrm{y}\end{array}$ & Percent & $\begin{array}{c}\text { Valid } \\
\text { Percent }\end{array}$ & $\begin{array}{c}\text { Cumulative } \\
\text { Percent }\end{array}$ \\
\hline \multirow[t]{3}{*}{ Valid } & YES & 7 & 70.0 & 70.0 & 70.0 \\
\hline & NO & 3 & 30.0 & 30.0 & 100.0 \\
\hline & Total & 10 & 100.0 & 100.0 & \\
\hline
\end{tabular}

The above table shows the attempt to cost cutting strategy used by the retailers. In big bazaar seven of the managers implement this strategy and consider it as one of the important one in increasing the sales of the business and the remaining three managers doesn't give consideration for this strategy.

Locate outlets in prime areas

\begin{tabular}{|r|r|r|r|r|}
\hline & Frequency & Percent & $\begin{array}{c}\text { Valid } \\
\text { Percent }\end{array}$ & $\begin{array}{c}\text { Cumulative } \\
\text { Percent }\end{array}$ \\
\hline Valid YES & 9 & 90.0 & 90.0 & 90.0 \\
NO & 1 & 10.0 & 10.0 & 100.0 \\
Total & 10 & 100.0 & 100.0 & \\
\hline
\end{tabular}

Locate outlets in prime areas is one of the vital strategy for success of any business. The managers of the big bazaar consider accessibility as one of the important service quality dimension therefore nine of the managers consider this strategy and one of the managers used this strategy before but later on it failed.

Use IT, bar code readers, RFID extensively for inventory management

\begin{tabular}{|r|r|r|r|r|}
\hline & Frequency & Percent & $\begin{array}{c}\text { Valid } \\
\text { Percent }\end{array}$ & $\begin{array}{c}\text { Cumulative } \\
\text { Percent }\end{array}$ \\
\hline Valid YES & 10 & 100.0 & 100.0 & 100.0 \\
\hline
\end{tabular}

Use IT, bar code readers, RFID extensively for inventory management is as strategy which is used to keep the proper record of all the goods in the retail store and to safe guard the goods. The strategy has been used by all the managers of the big bazaar 


\begin{tabular}{|l|r|r|r|r|}
\hline & Create different formats \\
\hline & $\begin{array}{c}\text { Freque } \\
\text { ncy }\end{array}$ & Percent & $\begin{array}{c}\text { Valid } \\
\text { Percent }\end{array}$ & $\begin{array}{c}\text { Cumulative } \\
\text { Percent }\end{array}$ \\
\hline Va YES & 5 & 50.0 & 50.0 & 50.0 \\
lid NO & 5 & 50.0 & 50.0 & 100.0 \\
Total & 10 & 100.0 & 100.0 & \\
\hline
\end{tabular}

The above results revealed that only fifty per managers consider this strategy and implement it in their business and the remaining fifty percent of the managers are against of this strategy. They feel that creating different formats may not lead to profit due to the intense competition.

Popularize private-label items

\begin{tabular}{|c|r|r|r|r|}
\hline & $\begin{array}{c}\text { Frequenc } \\
\mathrm{y}\end{array}$ & Percent & $\begin{array}{c}\text { Valid } \\
\text { Percent }\end{array}$ & $\begin{array}{c}\text { Cumulative } \\
\text { Percent }\end{array}$ \\
\hline Valid YES & 8 & 80.0 & 80.0 & 80.0 \\
NO & 2 & 20.0 & 20.0 & 100.0 \\
Total & 10 & 100.0 & 100.0 & \\
\hline
\end{tabular}

Popularize private-label items is a strategy that is mainly considered by most of the managers of the big bazaar. Out of ten managers eight of the managers consider this strategy and the remaining two managers don't consider this strategy.

Attempt consolidation, mergers, and acquisitions wherever synergies are possible

\begin{tabular}{|c|c|c|c|c|c|}
\hline & & Frequency & Percent & Valid Percent & $\begin{array}{l}\text { Cumulative } \\
\text { Percent }\end{array}$ \\
\hline \multirow[t]{3}{*}{ Valid } & YES & 7 & 70.0 & 70.0 & 70.0 \\
\hline & NO & 3 & 30.0 & 30.0 & 100.0 \\
\hline & Total & 10 & 100.0 & 100.0 & \\
\hline
\end{tabular}

The results revealed that $70 \%$ of the big bazaar managers attempt consolidation, mergers, and acquisitions wherever synergies are possible and the remaining 30\% of the manager's don't consider this strategy as the vital one.

\begin{tabular}{|c|c|c|c|c|c|}
\hline \multicolumn{6}{|c|}{ Go local - use localization strategy } \\
\hline & & Frequency & Percent & $\begin{array}{l}\text { Valid } \\
\text { Percent }\end{array}$ & $\begin{array}{c}\text { Cumulative } \\
\text { Percent }\end{array}$ \\
\hline \multirow[t]{3}{*}{ Valid } & YES & 7 & 70.0 & 70.0 & 70.0 \\
\hline & NO & 3 & 30.0 & 30.0 & 100.0 \\
\hline & Total & 10 & 100.0 & 100.0 & \\
\hline
\end{tabular}

Go local - use localization strategy is a strategy in order to attract the local customer towards the organized retailing $70 \%$ of the managers use localization strategy to attract more and more customers towards it and the remaining $30 \%$ of the managers don't use this strategy as they informed that they don't want to destroy the local traditional markets.

Move to tier II and tier III cities

\begin{tabular}{|c|r|r|c|c|}
\hline & $\begin{array}{c}\text { Frequenc } \\
\mathrm{y}\end{array}$ & Percent & $\begin{array}{c}\text { Valid } \\
\text { Percent }\end{array}$ & $\begin{array}{c}\text { Cumulative } \\
\text { Percent }\end{array}$ \\
\hline Valid YES & 10 & 100.0 & 100.0 & 100.0 \\
\hline
\end{tabular}


The above table reveals that all the managers want to move from tier II to tier III cities and make full utilization of the various opportunities creates in the new cities. Therefore the managers have created a separate team to carry out the feasibility study at different cities.

Anova (Growth of Business)

\begin{tabular}{|c|c|c|c|c|c|c|}
\hline & & Sum of Squares & $\mathrm{df}$ & Mean Square & $\mathrm{F}$ & Sig. \\
\hline $\begin{array}{l}\text { Join hands with other } \\
\text { organised retailers to form } \\
\text { an association }\end{array}$ & $\begin{array}{l}\text { Between Groups } \\
\text { Within Groups } \\
\text { Total }\end{array}$ & $\begin{array}{r}.400 \\
1.200 \\
1.600\end{array}$ & $\begin{array}{l}1 \\
8 \\
9\end{array}$ & $\begin{array}{l}.400 \\
.150\end{array}$ & 4.667 & .014 \\
\hline $\begin{array}{l}\text { Use professionally trained } \\
\text { security staff, CCTV, and } \\
\text { EAS (Electronic Article } \\
\text { Surveillance) to prevent } \\
\text { pilferage }\end{array}$ & $\begin{array}{l}\text { Between Groups } \\
\text { Within Groups } \\
\text { Total }\end{array}$ & $\begin{array}{r}.900 \\
1.200 \\
2.100\end{array}$ & $\begin{array}{l}1 \\
8 \\
9\end{array}$ & $\begin{array}{l}.900 \\
.150\end{array}$ & 9.035 & .004 \\
\hline Attempt cost-cutting & $\begin{array}{l}\text { Between Groups } \\
\text { Within Groups } \\
\text { Total }\end{array}$ & $\begin{array}{r}.100 \\
2.000 \\
2.100 \\
\end{array}$ & $\begin{array}{l}1 \\
8 \\
9\end{array}$ & $\begin{array}{l}.100 \\
.250\end{array}$ & 5.400 & .045 \\
\hline $\begin{array}{l}\text { Locate outlets in prime } \\
\text { areas }\end{array}$ & $\begin{array}{l}\text { Between Groups } \\
\text { Within Groups } \\
\text { Total }\end{array}$ & $\begin{array}{r}.100 \\
2.800 \\
2.900 \\
\end{array}$ & $\begin{array}{l}1 \\
8 \\
9 \\
\end{array}$ & $\begin{array}{l}.950 \\
.140\end{array}$ & 5.450 & .047 \\
\hline $\begin{array}{l}\text { Use IT, bar code readers, } \\
\text { RFID extensively for } \\
\text { inventory management }\end{array}$ & $\begin{array}{l}\text { Between Groups } \\
\text { Within Groups } \\
\text { Total }\end{array}$ & $\begin{array}{r}.300 \\
2.600 \\
2.700 \\
\end{array}$ & $\begin{array}{l}1 \\
8 \\
9 \\
\end{array}$ & $\begin{array}{l}.500 \\
.150\end{array}$ & 7.652. & 0.36 \\
\hline Create different formats & $\begin{array}{l}\text { Between Groups } \\
\text { Within Groups } \\
\text { Total }\end{array}$ & $\begin{array}{r}.100 \\
2.400 \\
2.500 \\
\end{array}$ & $\begin{array}{l}1 \\
8 \\
9 \\
\end{array}$ & $\begin{array}{l}.200 \\
.300\end{array}$ & 4.333 & .050 \\
\hline $\begin{array}{l}\text { Popularise private-label } \\
\text { items }\end{array}$ & $\begin{array}{l}\text { Between Groups } \\
\text { Within Groups } \\
\text { Total }\end{array}$ & $\begin{array}{r}.400 \\
2.200 \\
2.600 \\
\end{array}$ & $\begin{array}{l}1 \\
8 \\
9 \\
\end{array}$ & $\begin{array}{l}.430 \\
.150\end{array}$ & 6.667 & .010 \\
\hline $\begin{array}{l}\text { Attempt consolidation, } \\
\text { mergers, and acquisitions } \\
\text { wherever synergies are } \\
\text { possible }\end{array}$ & $\begin{array}{l}\text { Between Groups } \\
\text { Within Groups } \\
\text { Total }\end{array}$ & $\begin{array}{r}.100 \\
2.000 \\
2.100\end{array}$ & $\begin{array}{l}1 \\
8 \\
9\end{array}$ & $\begin{array}{l}.100 \\
.250\end{array}$ & .400 & .545 \\
\hline $\begin{array}{l}\text { Go local - use localisation } \\
\text { strategy }\end{array}$ & $\begin{array}{l}\text { Between Groups } \\
\text { Within Groups } \\
\text { Total }\end{array}$ & $\begin{array}{r}.100 \\
2.000 \\
2.100 \\
\end{array}$ & $\begin{array}{l}1 \\
8 \\
9 \\
\end{array}$ & $\begin{array}{l}.150 \\
.220\end{array}$ & 5.400 & .045 \\
\hline $\begin{array}{l}\text { Move to tier II and tier III } \\
\text { cities }\end{array}$ & $\begin{array}{l}\text { Between Groups } \\
\text { Within Groups } \\
\text { Total }\end{array}$ & $\begin{array}{r}.100 \\
2.000 \\
2.100\end{array}$ & $\begin{array}{l}1 \\
8 \\
9\end{array}$ & $\begin{array}{l}.200 \\
.100\end{array}$ & 5.356 & .046 \\
\hline
\end{tabular}

Join hands with other organized retailers to form an association: Analysis of variance revealed significant influence towards the growth of the organized retailing over Join hands with other organized retailers to form an association $(\mathrm{F}=4.667 ; \mathrm{P}=.014)$, as the $\mathrm{p}$ value is less than .05 it is significant hence we reject null hypothesis. Use professionally trained security staff, CCTV, and EAS (Electronic Article Surveillance) to prevent pilferage: ANOVA test revealed a significant difference with Use professionally trained security staff, CCTV, and EAS (Electronic Article Surveillance) to prevent pilferage and growth of business with F value of 9.035 and $\mathrm{P}$ value of .004. Hence there is a positive relationship between Use professionally trained security staff, CCTV, and EAS (Electronic Article Surveillance) to prevent pilferage and growth of the business.

Attempt cost-cutting: Significant difference was found for this component with respect to growth of the business, where $\mathrm{F}$ value was found to be 5.400 and $\mathrm{P}$ value of .045 . Hence it clearly indicates the significant relation between attempt to cost cutting and growth of the business.

Locate outlets in prime areas: Analysis of variance revealed significant difference for Locate outlets in prime areas and growth of the business, where $F$ value was 5.450 and $P$ value was .047 . The results shows that there is a positive relation between Locate outlets in prime areas and growth of the business 
Use IT, bar code readers, RFID extensively for inventory management: ANOVA for Use IT, bar code readers, RFID extensively for inventory management with growth of business revealed a significant difference with $\mathrm{F}$ value of 7.652 and P value of .036. Hence Use IT, bar code readers, RFID extensively for inventory management has significant impact on growth of the business

In the aspect of create different formats and the relationships between growth of the business. The anova method revealed a significant difference with $f$ value of 4.333 and the $p$ value of .050 . In the aspect of Popularize private-label items, anova $f$ value was $p$ values was 6.667 and the $p$ value was lower than 0.05 , which means that there are significant differences among Popularize private-label items and growth of business.

The ANOVA summary table reveals that the association between- Attempt consolidation, mergers, and acquisitions wherever synergies are possible and growth of the business, mean square is $.100, .150$. The Fratio is .400 , and the p-value $<.545$ indicates that there is no significant difference Attempt consolidation, mergers, and acquisitions wherever synergies are possible and growth of the business.

Go local - use localization strategy: ANOVA test revealed a significant difference with Go local - use localization strategy and growth of business with $F$ value of 5.400 and $P$ value of .045. Hence there is a positive relationship between Go local - use localization strategy and growth of the business.

To determine whether any significant differences existed between Moves to tier II and tier III cities and growth of the business a one way anova test was carried out. In one way anova analysis we compared the two attributes and the results revealed statistically significant differences with $\mathrm{p}$ value $.046(\mathrm{p}<.05)$.

\section{Conclusion}

The retail sector has played a phenomenal role throughout the world in increasing productivity of consumer goods and services. It is also the second largest industry in US in terms of numbers of employees and establishments. There is no denying the fact that most of the developed economies are very much relying on their retail sector as a locomotive of growth From the outcome of the study it can be concluded that the all the strategies considered in the study have significant effect on the growth of the business there for the management need to further effectively carry out these strategies.

References

[1] Cornelius, B., Natter, M. and Faure, C. (2010), “ How storefront displays influence retail store image Cornelius”, Journal of Retailing and Consumer Services, 17 (2), p.143-151.

[2] Devlin, J., Ennew, C., McKechnie, S. and Smith, A., 2007, “A study of time limited price promotions," The Journal of Product and Brand Management, Vol. 16 No. 4, pp. 280-286.

[3] Han, S. B., Chen, S. K. and Ebrahimpour, M., 2007, "The impact of ISO 9000 on TQM andbusiness performance," The Journal of Business and Economic Studies, Vol. 13, No. 2, pp. 1-25.

[4] He, M. Z., 2007, Marketing Manager of Company, Taiwan RT-mart, Interview Notes for Comparative Analysis of Marketing Strategies for Manufacturers' and Retailers' Brands, Taipei, Taiwan, R.O.C.

[5] Liberman, M. and Montgomery, D. (1988) "First-Mover Advantages", Strategic Management Journal, 9 (Summer Special Issue, 1988), p41-58.

[6] Lockett, A. and Thompson, S. (2001) "The Resource-Based View and Economics", Journal of Management, Vol. 27(6), p723-54

[7] Lee, M., Johnson, K.K.P. (1997), "Customer expectations for service at apparel retail outlets", Journal of Family and Consumer Sciences, Vol. 89 No.4, pp.26-30.

[8] Leszczyc, P.T.L.P., Timmermans, H. (2001), "Experimental choice analysis of shopping strategies", Journal of Retailing, Vol. 77 No.4, pp.493-509.

[9] Pieper, R. (1990) "Introduction: Human Resource Management: An International Comparison", in Pieper, R. (Eds), Human Resource Management: An International Comparison, de Gruyter, Berlin, p1-26.

[10] Porter, M.E. (1980) The Competitive Advantage on Nations, New York: Free Press. Pucik, V. (1992) "Globalization and Human Resource Management", in Barnett, C.K. (Eds),Globalizing Management: Creating and Leading the Competitive Organization, Wiley, New York, NY, p61-81.

[11] Qin, F. (2004) "Wal-Mart vs. Carrefour: Comparison between Strategies in Chinese Retail Market" (translated title) at http://finance.sina.com.cn on 21/06/2004. Accessed on 16/08/2007.

[12] Sparrow, P., Schuler, R. and Jackson, S. (1994) "Convergence or Divergence? Human Resource Practices and Policies for Competitive Advantage World-wide", International Journal of Human Resource Management, Vol. 5(2), p267-99.

[13] Stern, C. W. \& Stalk, G. Jr. (1998) (eds.), Perspectives on Strategy, M.A.: The Boston Consulting Group.

[14] Taylor, S., Beechler, S. and Napier, N. (1996) "Toward an Integrative Model of Strategic International Human Resource Management", Academy of Management Review, Vol. 21(4), p959-85.

[15] Taylor, S., Beechler, S. and Napier, N. (1996) "Toward an Integrative Model of Strategic International Human Resource Management", The Academy of Management Review, vol. 21(4), p959-985.

[16] Trunick, P.A. (2006) "Wal-Mart Reinvests Itself in China", Logistics Today, Vol. 47(1), p17-18.

[17] Tse D, Pan YG, and Au K. (1997) "How MNEs Choose Entry Modes and Form Appliances: The China Experience", Journal of International Business Studies, vol. 28(4), p779-805.

[18] Taewon Suh, Omar J. Khan (2003): "The effects of FDI inflows and ICT infrastructure on exporting in ASEAN/ATTA countries: A comparison with other regional blocs in emerging markets".

[19] Tatonga Gardner Rusike (2007): "Trends and determinants of inward Foreign Direct Investment to South Africa", eprints.ru.ac.za/1124/01/rusike-mcom.pdf. 